[Article]

www.whxb.pku.edu.cn

\title{
二荎并噻咯的合成及性能
}

\author{
曲红梅 ${ }^{1,}{ }^{*}$ 种泽鹏 ${ }^{1}$ 陈 旭 ${ }^{2}$ 门奕灿 ${ }^{1}$ 申海蛟 ${ }^{1}$ \\ ( ${ }^{1}$ 天津大学化工学院, 系统生物工程教育部重点实验室, 天津 $300072 ;{ }^{2}$ 天津金新材科技有限公司, 天津 300384 )
}

\begin{abstract}
摘要: 合成了一类新的二菜并噻咯类化合物, 它们分别是6,6-二甲基-1,2,3,4,8,9,10,11-八丙基二菜并噻 咯、6,6-二甲基-1,2,3,4,8,9,10,11-八丁基二萗并噻咯、6,6-二苯基-1,2,3,4,8,9,10,11-八丙基二菜并噻咯 和6,6-二苯基-1,2,3,4,8,9,10,11-八丁基二菜并噻咯。合成以炔烃为原料, 在二氯二茂锆的诱导作用下生 成铅杂环戊二烯, 再与卤代苯发生偶联反应得到二碘薺, 两分子二碘菜经正丁基锂锂化之后又可以反应 生成一分子联菜, 最后联菜与硅杂物反应得到不同取代基的二菜并噻咯类化合物。此合成方法不仅收率 高, 而且工艺简单。之后我们又采用核磁以及质谱对这几个分子进行了表征, 采用紫外-可见光谱测试、 荧光测试、循环伏安测试、热重分析测试以及高斯计算, 对它们的光学性能、电化学性能、稳定性等进 行了测试。实验结果表明它们有着相似的光吸收带以及很低的HOMO值 $(-5.50 \mathrm{eV})$ 。它们的热分解温度 都在 $300{ }^{\circ} \mathrm{C}$ 左右, 表明它们有良好的热稳定性。最后, 我们用6,6-二甲基-1,2,3,4,8,9,10,11-八丁基二荎 并噻咯做为发光层制作了电致发光器件, 该器件可以发明亮的蓝紫光。
\end{abstract}

关键词: 二菜并噻咯; 偶联反应; 锂化反应; 循环伏安; 热重分析; 有机电致发光器件 中图分类号: 0649

\section{Synthesis and Properties of a Series of Dinaphthosiloles}
QU Hong-Mei ${ }^{1, *}$
CHONG Ze-Peng ${ }^{1}$
CHEN Xu ${ }^{2} \quad$ MEN Yi-Can ${ }^{1}$
SHEN Hai-Jiao ${ }^{1}$

$\left({ }^{1}\right.$ Key Laboratory of Systems Bioengineering (Ministry of Education), School of Chemical Engineering and Technology, Tianjin University, Tianjin 300072, P. R. China; ${ }^{2}$ Tianjin Kingsrial S\&T Company, Limited, Tianjin 300384, P. R. China)

\begin{abstract}
Siloles constitute an important emerging class of photoluminescent materials. A series of compounds consisting of silole cores and fused naphthalene were synthesized and characterized: 6,6-dimethyl-1,2,3,4,8,9,10,11-octapropyl-6H-dinaphtho[2,3-b:2',3'-d]silole,1,2,3,4,8,9,10,11-octabutyl-6, 6-dimethyl-6H-dinaphtho[2,3-b:2',3'-d]silole, 6,6-diphenyl-1,2,3,4,8,9,10,11-octapropyl-6H-dinaphtho[2,3b:2',3'-d]silole, and 1,2,3,4,8,9,10,11-octabutyl-6,6-diphenyl-6H-dinaphtho[2,3-b:2',3'-d]silole. These dinaphthalene-fused siloles were synthesized from diiodonaphthalene, which was prepared by a direct coupling method. Subsequent reaction in the presence of $n$-butyllithium yielded 3,3'-diiodo-2,2'binaphthalene. Direct substitution of two chloride ions from $\mathrm{Ph}_{2} \mathrm{SiCl}_{2}$ or $\mathrm{Me}_{2} \mathrm{SiCl}_{2}$ with 3,3'-dilithio$2,2^{\prime}$-binaphthalene then yielded the multi-substituted silole. Nuclear magnetic resonance spectroscopy and high-resolution mass spectrometry were used to characterize the structures of the siloles. Their optical and electronic properties were investigated using ultraviolet-visible absorption spectroscopy, photoluminescence spectroscopy, cyclic voltammetry, and density functional theory calculations. The dinaphthalene-fused siloles exhibited similar absorption and emission peaks. Their deep highest occupied molecular orbital level at approximately $-5.5 \mathrm{eV}$ indicated that they were chemically stable. Differential
\end{abstract}

Received: December 21, 2016; Revised: February 20, 2017; Published online: February 21, 2017.

${ }^{*}$ Corresponding author. Email: ququhongmei@126.com; Tel: +86-13512888615.

The project was supported by the National Natural Science Foundation of China (21102099).

国家自然科学基金(21102099)资助项目

(C) Editorial office of Acta Physico-Chimica Sinica 
scanning calorimetry and thermogravimetric analysis indicated that the siloles were stable up to $309^{\circ} \mathrm{C}$. A multilayer electroluminescent device was fabricated using 1,2,3,4,8,9,10,11-octabutyl-6,6-dimethyl$6 H$-dinaphtho[2,3-b:2',3'-d]silole as a light-emitting layer. The resulting device produced bright blue emission, indicating that these siloles may be suitable materials in organic light-emitting devices.

Key Words: Dinaphthosilole; Coupling reaction; Lithiation reaction; Cyclic voltammetry; Thermogravimetric analysis; Organic electroluminescent device

\section{Introduction}

Siloles, including benzosiloles and heteroarene-fused siloles, have received increasing attention in recent years. Siloles are $\sigma^{*}-\pi^{*}$ conjugated molecules. The interaction between the $\sigma^{*}$ orbital of the silicon-carbon bond and the $\pi^{*}$ orbital of the butadiene segment leads to a low-lying lowest unoccupied molecular orbital (LUMO) energy level. This endows siloles with a high electron affinity and high electron mobility ${ }^{1,2}$. Various silole-based functional materials have been developed, and some exhibit excellent photophysical and electronic properties $^{3-8}$. Tang et al. ${ }^{9}$ reported silole-based derivatives with high external electroluminescence (EL) efficiencies. Siloles are now widely used in organic EL devices, organic solar cells, and chemosensors for explosive detection and ion monitoring ${ }^{10-19}$.

Facile syntheses and derivations of silole scaffolds are important in synthetic and materials chemistry. Developing practical and efficient functionalization methods is important for determining their inherent electronic characteristics. A common method for modifying the optical and electronic properties of siloles is to introduce electron donating or withdrawing substituents, such as heteroatoms or aryl groups ${ }^{20}$. Another approach is to extend the $\pi$-system by annulation with aromatic rings. Introducing fused aromatics is especially promising, because it can perturb the electronic structure of the parent silole framework. This can provide the silole framework with new properties, such as charge-carrier mobility and luminescence ${ }^{21}$

These findings have encouraged the syntheses of siloles with fused low-molecular-weight compounds such as thiophene and benzene $^{22-30}$. However, there are no reports of siloles with fused naphthalene. To explore these siloles and study the impact of different substituents on their properties, four new siloles were synthesized (Scheme 1). The current synthesis is much simpler than previously reported syntheses, which are often tedious and difficult. The synthesis and physical, optical, and electrochemical characterizations of these compounds are described. A thin film device containing one of the siloles was also fabricated.

\section{Experimental methods}

\subsection{Materials and equipment}

All reactions were carried out under dry, oxygen-free nitrogen atmospheres using standard Schlenk techniques. Tetrahydrofuran(THF) was distilled over sodium and benzophenone under a nitrogen atmosphere. Other organic solvents and materials were of reagent grade, and were used without further purification. Column chromatography was performed using silica gel (200-300 mesh). ${ }^{1} \mathrm{H}$ and ${ }^{13} \mathrm{C}$ nuclear magnetic resonance (NMR) spectra were recorded on a Bruker $400 \mathrm{MHz}$ spectrometer. High-resolution mass spectra (HRMS) were recorded on an FT-ICR mass spectrometer, using EI (Electron Ionization). Ultraviolet-visible (UV-Vis) absorption spectra were recorded on a Thermo Evolution 300 spectrometer. Electrochemical measurements were performed using a Hokuto CHI660 voltammetric analyzer, with a three-electrode cell in a solution of tetrabutylammonium perchlorate $\left(0.1 \mathrm{~mol} \cdot \mathrm{L}^{-1}\right)$ in dichloromethane at a scan rate of $100 \mathrm{mV} \cdot \mathrm{s}^{-1}$. Pt wire and glassy carbon and $\mathrm{Ag} / \mathrm{AgNO}_{3}$ electrodes were used as the counter, working, and reference electrodes, respectively. The potential was corrected against $\mathrm{Fc} / \mathrm{Fc}^{+}$. Differential scanning calorimetry (DSC) and thermogravimetric analyses (TGA) were performed using Mettler-Toledo (model DSC 1/500, Switzerland) and Mettler-Toledo (model TGA/SDTA 851e, Switzerland) instruments, respectively. Thermal analyses were carried out under a nitrogen flow at a heating rate of $10{ }^{\circ} \mathrm{C} \cdot \mathrm{min}^{-1}$ from room temperature.

\subsection{Device fabrication}

The device structure is shown in Fig.1. The device was fabricated on a glass substrate coated with indium tin oxide (ITO) with a sheet resistance of approximately $20 \Omega \cdot \square^{-1}$. The ITO glass was first cleaned by successively ultrasonicating in detergent, deionized water, acetone, and isopropanol (15 min each), to remove organic contaminants. Organic, $\mathrm{LiF}$, and $\mathrm{Al}$

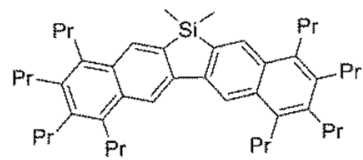

$4 a$

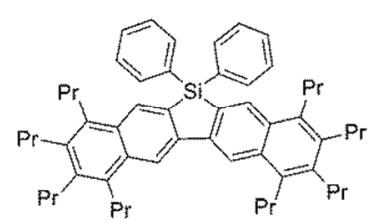

$4 c$

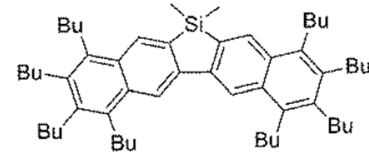

$4 \mathrm{~b}$

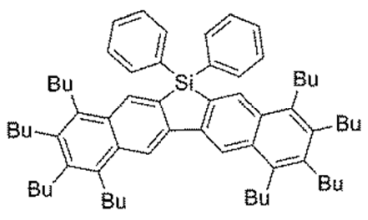

$4 d$
Scheme 1 Molecular structures of the synthesized dinaphthosiloles 


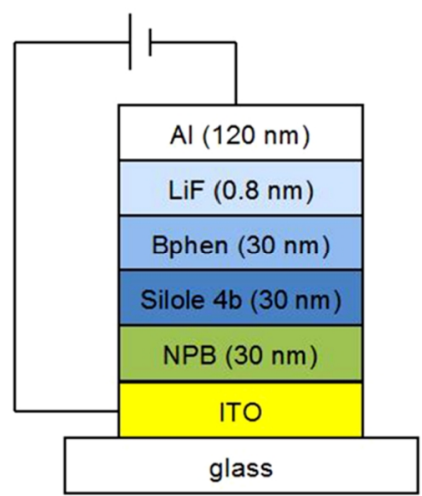

Fig.1 Architecture of the fabricated device

layers were deposited on the ITO substrate using a BOC Edwards Auto-500 thermal evaporation coating system, which was located in a M. Braun 20G glove box (pressure of approximately $7 \times 10^{-5} \mathrm{~Pa}$ ). Deposition rates and thicknesses were monitored using a quartz crystal oscillator. The evaporation rate was $0.05 \mathrm{~nm} \cdot \mathrm{s}^{-1}$ for the organic layers. $\mathrm{LiF}$ and $\mathrm{Al}$ were evaporated onto the organic layer as the cathode, at rates of 0.01 and $0.3 \mathrm{~nm} \cdot \mathrm{s}^{-1}$, respectively. The active area of the emitting device was $3 \mathrm{~mm} \times 3 \mathrm{~mm}$. All measurements were carried out in ambient atmosphere at room temperature.

\subsection{Synthesis}

\subsubsection{1,2,3,4-tetrabutyl-6,7-diiodonaphthalene(2b)}

In a solution of $\mathrm{Cp}_{2} \mathrm{ZrCl}_{2}(3.79 \mathrm{~g}, 13 \mathrm{mmol})$ in THF $(50 \mathrm{~mL})$ in a $250 \mathrm{~mL}$ Schlenk tube, adding $n$-butyllithium $\left(2.5 \mathrm{~mol} \cdot \mathrm{L}^{-1}\right.$ in hexane solution, $10 \mathrm{~mL}, 25 \mathrm{mmol})$ at $-78{ }^{\circ} \mathrm{C}$. After the mixture stirred for $1 \mathrm{~h}$ at the same temperature, 5-decyne (3.59 $\mathrm{mL}, 20 \mathrm{mmol}$ ) was added, and the reaction mixture was warmed to room temperature for $3 \mathrm{~h}$ to form tetrabutylzirconacyclopentadiene (1b). Then copper chloride (1.18 g, 12 mmol), 1,3-dimethyl-3,4,5,6-tetrahydro-2(1H)-pyrimidinone (DMPU) $(2.5 \mathrm{~mL}, 15 \mathrm{mmol})$, and 1,2,4,5- tetraiodobenzene $(5.28 \mathrm{~g}, 10 \mathrm{mmol})$ was added and stirred at $50{ }^{\circ} \mathrm{C}$ for $1 \mathrm{~h}$. The reaction mixture was quenched by addition of $\mathrm{HCl}\left(3 \mathrm{~mol} \cdot \mathrm{L}^{-1}\right)$ and extracted with $\mathrm{Et}_{2} \mathrm{O}(3 \times 30 \mathrm{~mL})$. The organic layer was separated, dried with magnesium sulfate, and concentrated in vacuo, leaving a dark oily residue. Column chromatography on silica gel $(100 \%$ of hexane as eluent) afforded the corresponding product $\mathbf{2 b}(3.5 \mathrm{~g}, 58 \%)$ as a pale yellow solid. ${ }^{1} \mathrm{H}$ NMR (400 MHz, $\mathrm{CDCl}_{3}$ ) $\delta: 8.48(\mathrm{~s}, 2 \mathrm{H}), 2.91$ (t, $J=7.1 \mathrm{~Hz}$, $4 \mathrm{H}), 2.71(\mathrm{t}, J=7.8 \mathrm{~Hz}, 4 \mathrm{H}), 1.70-1.35(\mathrm{~m}, 16 \mathrm{H}), 1.13-0.86$ $(\mathrm{m}, 12 \mathrm{H})$.

\subsubsection{6,7-diiodo-1,2,3,4-tetrapropylnaphthalene(2a)}

The procedure was analogous to that described for $\mathbf{2 b}$. Pale yellow solid, yield $65 \%$. ${ }^{1} \mathrm{H}$ NMR $\left(400 \mathrm{MHz}, \mathrm{CDCl}_{3}\right) \delta: 8.47$ (s, 2H), 2.88 (t, $J=8.3 \mathrm{~Hz}, 4 \mathrm{H}), 2.68$ (t, $J=8.4 \mathrm{~Hz}, 4 \mathrm{H})$, $1.65-1.51(\mathrm{~m}, 8 \mathrm{H}), 1.09$ (t, $J=7.3 \mathrm{~Hz}, 12 \mathrm{H})$.

\subsubsection{5, 5',6,6',7,7',8, 8'-octabutyl-3,3'-diiodo-2,2'- binaphthalene(3b)}

2b $(0.91 \mathrm{~g} 1.5 \mathrm{mmol})$ and dry THF $(5 \mathrm{~mL})$ were placed in a $50 \mathrm{~mL}$ Schlenk tube, the mixture was cooled to $-78{ }^{\circ} \mathrm{C}$. Then with stirring, adding $n$-butyllithium $\left(2.5 \mathrm{~mol} \cdot \mathrm{L}^{-1}\right.$ in hexane solution, $0.3 \mathrm{~mL}, 0.75 \mathrm{mmol}$ ) at $-78{ }^{\circ} \mathrm{C}$ over a period of $3 \mathrm{~h}$. After the addition was completed, the reaction mixture was warmed up to room temperature and stirred for $20 \mathrm{~h}$. After extraction with ethyl acetate $(3 \times 5 \mathrm{~mL})$, the organic layer was combined and washed with water $(3 \times 5 \mathrm{~mL})$. After drying over $\mathrm{MgSO}_{4}$, the solvent was evaporated in vacuo to give a yellow solid which was purified by column chromatography over silica gel ( $100 \%$ of hexane as eluent) to give $\mathbf{3 b}$ as a white crystalline solid (0.53 g, 74\%). ${ }^{1} \mathrm{H}$ NMR (400 MHz, $\left.\mathrm{CDCl}_{3}\right) \delta: 8.65$ (s, 2H), $7.92(\mathrm{~s}, 2 \mathrm{H}), 3.17-2.90(\mathrm{~m}, 8 \mathrm{H}), 2.81(\mathrm{~m}, 8 \mathrm{H}), 1.82-1.41$ $(\mathrm{m}, 32 \mathrm{H}), 1.08(\mathrm{~m}, 18 \mathrm{H}), 0.96(\mathrm{t}, J=7.3 \mathrm{~Hz}, 6 \mathrm{H}) \cdot{ }^{13} \mathrm{C} \mathrm{NMR}$ $\left(400 \mathrm{MHz}, \mathrm{CDCl}_{3}\right) \delta: 144.6,138.4,135.2,134.8,133.3,132.6$, 130.6, 126.5, 97.0, 33.8, 31.8, 30.2, 28.8, 23.7, 23.6, 23.5, 22.8, 14.2; HRMS (EI) calcd for $\mathrm{C}_{52} \mathrm{H}_{76} \mathrm{I}_{2}$ : 954.4036. Found: 954.4039 .

\subsubsection{3,3'-diiodo-5, 5',6,6', 7, 7', 8, 8'-octapropyl-2,2'- binaphthalene(3a)}

The procedure was analogous to that described for $\mathbf{3 b}$. White crystalline solid, yield $75 \%$. ${ }^{1} \mathrm{H}$ NMR $\left(400 \mathrm{MHz}, \mathrm{CDCl}_{3}\right) \delta$ : $8.62(\mathrm{~s}, 2 \mathrm{H}), 7.89$ (s, 2H), 3.16-2.86 (m, 8H), 2.85-2.66 (m, $8 \mathrm{H}), 2.02-1.42(\mathrm{~m}, 16 \mathrm{H}), 1.23-1.09(\mathrm{~m}, 18 \mathrm{H}), 1.05(\mathrm{t}, J=7.3$ $\mathrm{Hz}, 6 \mathrm{H}) .{ }^{13} \mathrm{C}$ NMR $\left(400 \mathrm{MHz}, \mathrm{CDCl}_{3}\right) \delta: 144.6,138.4,135.2$, 134.7, 133.3, 132.5, 130.6, 126.5, 97.04, 32.8, 31.3, 24.9, 15.2, 15.1, 14.9; HRMS (EI) calcd for $\mathrm{C}_{44} \mathrm{H}_{60} \mathrm{I}_{2}: 842.2784$. Found: 842.2781 .

\subsubsection{1,2,3,4,8,9,10,11-octabutyl-6,6-dimethyl- $6 \mathrm{H}$ - dinaphtho[2,3-b:2',3'-d]silole (4b)}

$3 \mathbf{b}(0.76 \mathrm{~g}, 0.8 \mathrm{mmol})$ and dry THF $(5 \mathrm{~mL})$ were placed in a $50 \mathrm{~mL}$ Schlenk tube and the mixture was cooled to $-78{ }^{\circ} \mathrm{C}$. Then $t$-butyllithium $\left(1.3 \mathrm{~mol} \cdot \mathrm{L}^{-1}\right.$ in pantane; $2.5 \mathrm{~mL}, 3.28$ mmol) was added dropwise with constant stirring. After completion, the reaction mixture was warmed up to room temperature and stirred for $20 \mathrm{~h}$ to form $5,5^{\prime}, 6,6^{\prime}, 7,7^{\prime}, 8,8^{\prime}$ octabutyl-3,3'-lithium-2,2'-binaphthalene. Then, this solution was added dropwise to a solution of dichlorodimethylsilane $(0.12 \mathrm{~g}, 0.95 \mathrm{mmol})$ in dry THF $(50 \mathrm{~mL})$ at room temperature and stirred for $1 \mathrm{~d}$. After extraction with chloroform $(3 \times 20$ $\mathrm{mL}$ ), the organic layer was combined and washed with water $(3 \times 20 \mathrm{~mL})$. After drying over $\mathrm{MgSO}_{4}$, the solvent was evaporated in vacuo to give a yellow solid which was purified by column chromatography over silica gel (hexane/ethyl acetate volume ratio $=100: 1$, ) to give $\mathbf{4 b}$ as a white crystalline solid (0.39 g, 58\%). ${ }^{1} \mathrm{H}$ NMR (400 MHz, $\left.\mathrm{CDCl}_{3}\right) \delta: 8.67$ (s, $2 \mathrm{H}), 8.37(\mathrm{~s}, 2 \mathrm{H}), 3.14-3.25(\mathrm{~m}, 8 \mathrm{H}), 2.85-2.81(\mathrm{~m}, 8 \mathrm{H})$, $1.84-1.60(\mathrm{~m}, 32 \mathrm{H}), 1.17-1.07(\mathrm{~m}, 24 \mathrm{H}), 0.599(\mathrm{~s}, 6 \mathrm{H}) ;{ }^{13} \mathrm{C}$ NMR (400 MHz, $\left.\mathrm{CDCl}_{3}\right) \delta: 143.3,137.9,136.8,136.1,134.5$, $132.6,130.9,129.8,115.4$, , 33.8, 33.7, 33.6, 30.1, 29.9, 28.8, 28.6, 23.7, 23.6, 23.5, 14.3, 14.1, 13.9, 1.0; HRMS (EI) calcd for $\mathrm{C}_{54} \mathrm{H}_{82} \mathrm{Si}$ : 758.6186. Found: 758.6165.

\subsubsection{6,6-dimethyl-1,2,3,4,8,9,10,11-octapropyl-6H- dinaphtho[2,3-b:2',3'-d]silole (4a)}

The procedure was analogous to that described for $\mathbf{4 b}$. White 


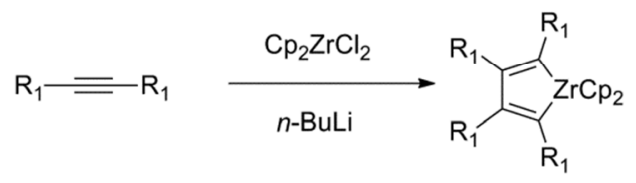

1a: $R_{1}=P r$ 1b: $R_{1}=B u$

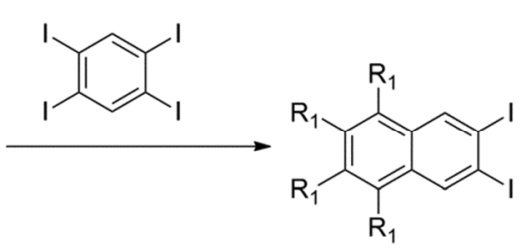

2a: $R_{1}=P r$

2b: $R_{1}=B u$

Scheme 2 Synthesis of the diiodonaphthalenes

crystalline solid, yield $60 \%$. ${ }^{1} \mathrm{H}$ NMR $\left(400 \mathrm{MHz}, \mathrm{CDCl}_{3}\right) \delta$ : $8.62(\mathrm{~s}, 2 \mathrm{H}), 8.32(\mathrm{~s}, 2 \mathrm{H}), 3.29-3.03(\mathrm{~m}, 8 \mathrm{H}), 2.79(\mathrm{~m}, 8 \mathrm{H})$, $1.81(\mathrm{t}, J=20.1 \mathrm{~Hz}, 8 \mathrm{H}), 1.64(\mathrm{~m}, 8 \mathrm{H}), 1.39-1.24(\mathrm{~m}, 6 \mathrm{H})$, $1.22-1.08(\mathrm{~m}, 18 \mathrm{H}), 0.57$ (s, 6H). ${ }^{13} \mathrm{C} \mathrm{NMR}\left(400 \mathrm{MHz}, \mathrm{CDCl}_{3}\right)$ $\delta: 143.4,137.9,136.9,136.3,134.7,132.8,131.1,129.9,115.6$, 32.8, 31.8, 31.3, 29.9, 25.2, 25.0, 15.2, -1.9; HRMS (EI) calcd for $\mathrm{C}_{46} \mathrm{H}_{66} \mathrm{Si}: 646.4934$. Found: 646.4930 .

\subsubsection{6,6-diphenyl-1,2,3,4,8,9,10,11-octapropyl-6H-} dinaphtho[2,3-b:2',3'-d]silole (4c)

The procedure was analogous to that described for $\mathbf{4 b}$. White crystalline solid, yield 50\%. ${ }^{1} \mathrm{H}$ NMR (400 $\left.\mathrm{MHz}, \mathrm{CDCl}_{3}\right) \delta$ : $8.70(\mathrm{~s}, 2 \mathrm{H}), 8.46(\mathrm{~s}, 2 \mathrm{H}), 7.82-7.68(\mathrm{~m}, 4 \mathrm{H}), 7.45-7.31$ (m, 6H), 3.19-3.15 (m, 4H), 3.08-3.04 (m, 4H), 2.85-2.68 (m, $8 \mathrm{H}), 1.89-1.79(\mathrm{~m}, 4 \mathrm{H}), 1.75-1.52(\mathrm{~m}, 12 \mathrm{H}), 1.31-1.22(\mathrm{~m}$, $6 \mathrm{H}), 1.17-1.04(\mathrm{~m}, 18 \mathrm{H}) .{ }^{13} \mathrm{C} \mathrm{NMR}\left(400 \mathrm{MHz}, \mathrm{CDCl}_{3}\right) \delta$ : 144.0, 138.4, 137.2, 135.8, 134.9, 134.7, 134.2, 133.1, 131.8, 131.3, 130.0, 128.2, 116.0, 32.9, 31.8, 31.2, 25.1, 24.9, 24.9, 15.3, 14.9; HRMS (EI) calcd for $\mathrm{C}_{56} \mathrm{H}_{70} \mathrm{Si}$ : 770.5247. Found: 770.5245

\subsubsection{1,2,3,4,8,9,10,11-octabutyl-6,6-diphenyl-6H- dinaphtho[2,3-b:2',3'-d]silole (4d)}

The procedure was analogous to that described for $\mathbf{4 b}$. White crystalline solid, yield $49 \% .{ }^{1} \mathrm{H}$ NMR $\left(400 \mathrm{MHz}, \mathrm{CDCl}_{3}\right) \delta$ : $8.71(\mathrm{~s}, 2 \mathrm{H}), 8.52(\mathrm{~s}, 2 \mathrm{H}), 7.86-7.76(\mathrm{~m}, 4 \mathrm{H}), 7.45-7.34(\mathrm{~m}$, $6 \mathrm{H}), 3.22(\mathrm{t}, J=7.3 \mathrm{~Hz}, 4 \mathrm{H}), 3.11(\mathrm{t}, J=7.0 \mathrm{~Hz}, 4 \mathrm{H})$, 2.92-2.71 (m, 8H), 1.88-1.50 (m, 32H), $1.14(\mathrm{t}, J=7.2 \mathrm{~Hz}$, $6 \mathrm{H}), 1.10-0.09(\mathrm{~m}, 18 \mathrm{H}) ;{ }^{13} \mathrm{C}$ NMR $\left(400 \mathrm{MHz}, \mathrm{CDCl}_{3}\right) \delta$ : $144.0,138.4,135.7,134.9,134.7,134.3,133.0,131.8,131.2$, 129.9, 128.2, 115.9, 33.9, 30.2, 28.8, 23.7, 14.4, 14.3, 14.1; HRMS (EI) calcd for $\mathrm{C}_{64} \mathrm{H}_{86} \mathrm{Si}: 882.6499$. Found: 882.6501 .

\section{Results and discussion}

\subsection{Synthesis and characterization}

The diiodonaphthalene compounds were synthesized in two steps, as shown in Scheme 2. Zirconacyclopentadienes were prepared from oct-4-yne or dec-5-yne. The coupling reaction proceeded in the presence of $\mathrm{CuCl}$ and DMPU. The corresponding diiodonaphthalenes $\mathbf{2 a}$ and $\mathbf{2 b}$ were obtained in yields of $65 \%$ and $58 \%$, respectively. This coupling method also allows a direct ring extension of diiodoaromatic compounds such as diiodobenzene and diiodonaphthalene.

The procedure for synthesizing the dinaphthosiloles is shown in Scheme 3. After lithiation with $n$-butyllithium, two diiodonaphthalene molecules reacted to afford 3,3'-diiodo-2,2'binaphthalene (3a or $\mathbf{3 b}$ ). The direct substitution of two chloride ions from $\mathrm{Ph}_{2} \mathrm{SiCl}_{2}$ or $\mathrm{Me}_{2} \mathrm{SiCl}_{2}$ with 3,3'-dilithio-2,2'binaphthalene then afforded the multi-substituted siloles. The structures of the compounds were characterized by HRMS, and ${ }^{1} \mathrm{H}$ and ${ }^{13} \mathrm{C}$ NMR spectroscopies. All characterization date were consistent with the proposed structures. All prepared compounds were sufficiently soluble in common organic solvents such as chloroform, dichloromethane, toluene, ethyl acetate and ether, but were insoluble in water.

The siloles $\mathbf{4 a}, \mathbf{4 b}, \mathbf{4 c}$ and $\mathbf{4 d}$ were isolated as white crystalline solids in yields of $60 \%, 58 \%, 50 \%$, and $49 \%$, respectively. The yields of $\mathbf{4 c}$ and $\mathbf{4 d}$ were slightly lower than those of $\mathbf{4 a}$ and $\mathbf{4 b}$, because of the effects of spatial congestion. The phenyl groups of $\mathrm{Ph}_{2} \mathrm{SiCl}_{2}$ inhibited the approach of bulky naphthalene groups, which reduced the reaction yield.

\subsection{Thermal analysis}

The thermal stabilities of the siloles were investigated by TGA and DSC measurements. TGA showed that the compounds exhibited excellent thermal stability. The onset decomposition temperatures of $\mathbf{4 a}, \mathbf{4 b}, \mathbf{4 c}$, and $\mathbf{4 d}$ at $5 \%$ weight loss were $251,257,309$, and $288{ }^{\circ} \mathrm{C}$, respectively. This indicated that the phenyl-substituted $\mathbf{4 c}$ and $\mathbf{4 d}$ were more thermally stable than the methyl-substituted $\mathbf{4 a}$ and $\mathbf{4 b}$. The higher molecular weights of $\mathbf{4 c}$ and $\mathbf{4 d}$ may have contributed to their higher thermal stabilities. The melting<smiles>[R]c1c([R])c([R])c2cc(I)c(I)cc2c1[R]</smiles>

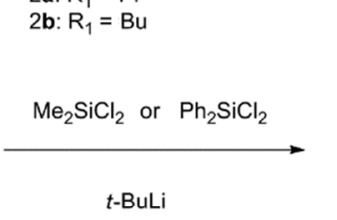<smiles>[R]c1c([R])c([R])c2cc3c(cc2c1[R])-c1cc2c([R])c([R])c([R])c([R])c2cc1[Si]3([R])[R]</smiles>

$$
\begin{aligned}
& \text { 4a: } R_{1}=P r, R_{2}=M e \\
& \text { 4b: } R_{1}=B u, R_{2}=M e \\
& \text { 4c: } R_{1}=P r, R_{2}=P h \\
& \text { 4d: } R_{1}=B u, R_{2}=P h
\end{aligned}
$$

Scheme 3 Synthesis of the dinaphthosiloles 
points $\left(T_{\mathrm{m}}\right)$ of the siloles were determined by DSC. The samples were heated to $350{ }^{\circ} \mathrm{C}$ at a rate of $10{ }^{\circ} \mathrm{C} \cdot \mathrm{min}^{-1}$, and were then cooled to room temperature. The melting temperatures of $\mathbf{4 a}, \mathbf{4 b}, \mathbf{4 c}$, and $\mathbf{4 d}$ were $160,137,175$, and $156{ }^{\circ} \mathrm{C}$, respectively. No crystallization peaks were observed in the DSC cooling scans. TGA and DSC curves of $\mathbf{4 a}, \mathbf{4 b}$, 4c, and 4d are shown in Figs.2 and 3, respectively.

\subsection{Photochemical properties}

UV-Vis absorption and photoluminescence (PL) spectra of dilute $\left(2.0 \times 10^{-5} \mathrm{~mol} \cdot \mathrm{L}^{-1}\right)$ solutions of $4 \mathbf{a}, \mathbf{4 b}, \mathbf{4 c}$, and $4 \mathbf{d}$ in $\mathrm{CHCl}_{3}$ are shown in Fig. 4 and Fig.5, respectively. Detailed photophysical data are shown in Table 1.

Two absorbance bands were observed in the UV-Vis absorption spectra in Fig.4. A broad lower energy band was centered near $240 \mathrm{~nm}$, and a higher energy band was centered near $300 \mathrm{~nm}$. The latter was attributed to the $\pi-\pi^{*}$ transition of the silole core. The absorption maximum of $\mathbf{4} \mathbf{c}$ was

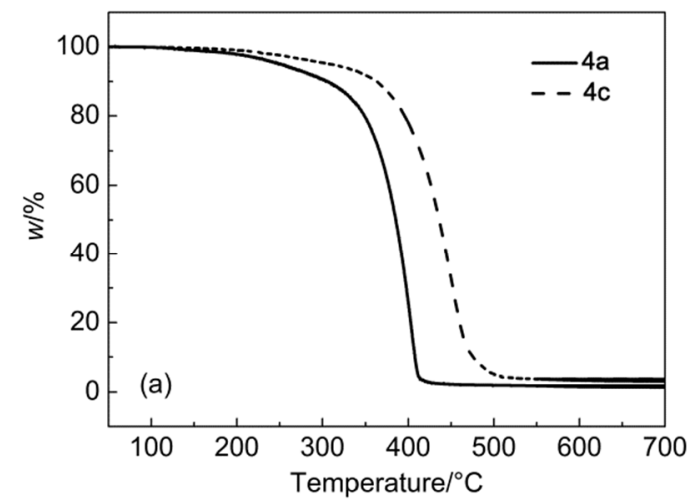

Fig.2 TGA curves of (a) $4 \mathrm{a}$ and $4 \mathrm{c}$ and (b) $4 \mathrm{~b}$ and $4 \mathrm{~d}$, recorded at a heating rate $0{ }^{\circ}{ }^{\circ} \mathrm{C} \cdot \mathrm{min}^{-1}$ under a nitrogen atmosphere
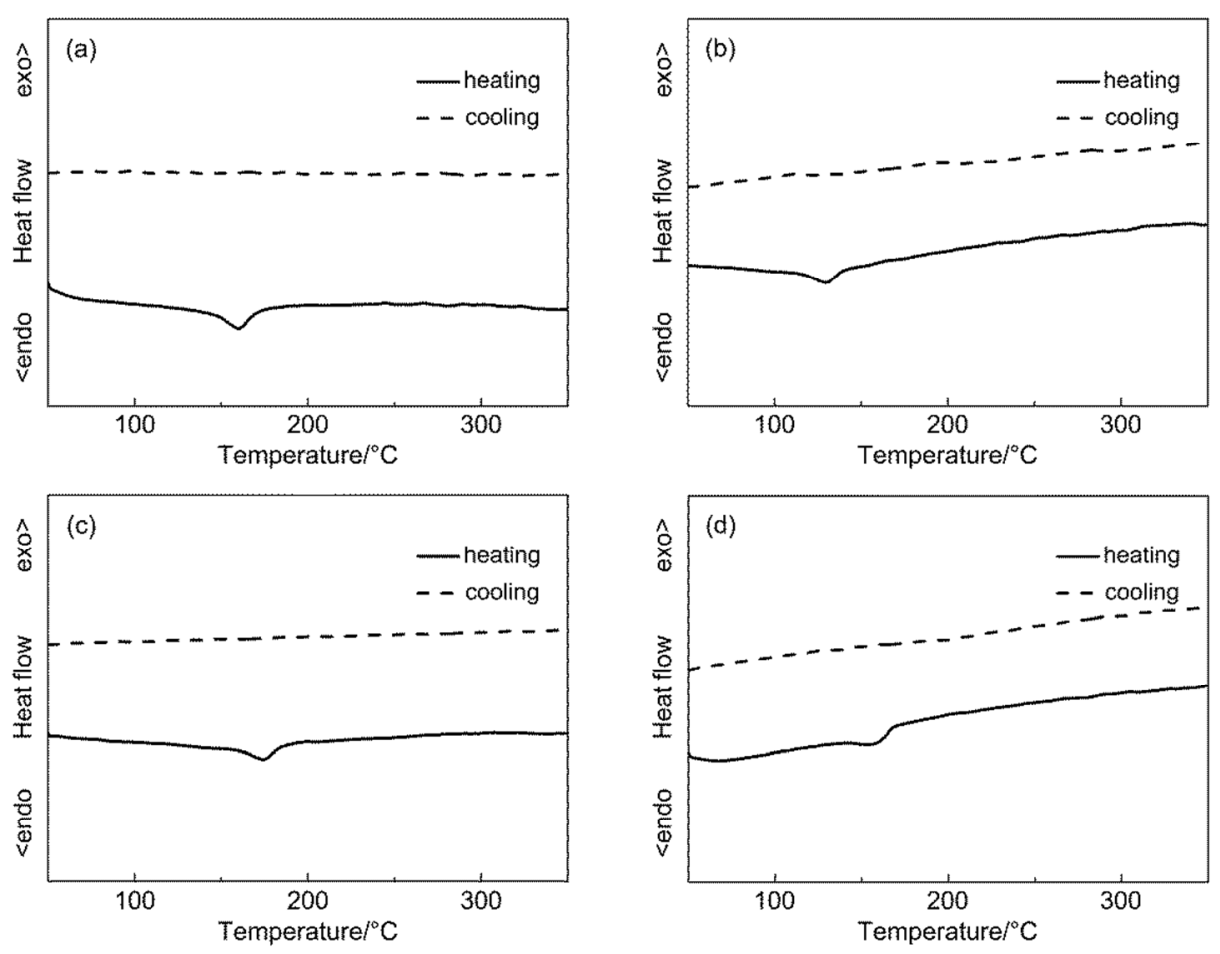

Fig.3 DSC curves of (a) 4a, (b) 4b, (c) $4 c$, and (d) $4 d$ located at $303 \mathrm{~nm}$, and was slightly red-shifted relative to that of $4 \mathbf{a}(299 \mathrm{~nm})$. A similar small red-shift was also observed in the absorption spectra of $\mathbf{4 d}$ and $\mathbf{4 b}$ (Table 1). These findings are consistent with previous observations of silole derivatives, which were attributed to the inductive effect $^{31,32}$ of the additional phenyl rings at the 1-position of the silole rings. The optical band gaps $\left(\Delta E^{\text {opt }}\right)$ of the silole compounds were estimated from the onsets of their UV-Vis absorption spectra. The absorption onsets of $\mathbf{4 a}, \mathbf{4 b}, \mathbf{4 c}$, and 4d in chloroform occurred at 391, 392, 396, and $395 \mathrm{~nm}$, respectively, indicating band gaps of approximately 3.17 , $3.16,3.13$, and $3.14 \mathrm{eV}$, respectively.

The long-wavelength emission resulted from the extended $\pi$ conjugation of the silole rings. Fig. 5 shows the PL spectra of dilute $\left(2.0 \times 10^{-5} \mathrm{~mol} \cdot \mathrm{L}^{-1}\right)$ solutions of $4 \mathbf{a}, \mathbf{4 b}, \mathbf{4} \mathbf{c}$, and $\mathbf{4 d}$ in $\mathrm{CHCl}_{3}$. All spectra exhibited emission peaks between 410 and $418 \mathrm{~nm}$, corresponding to a purple-blue color. Compared

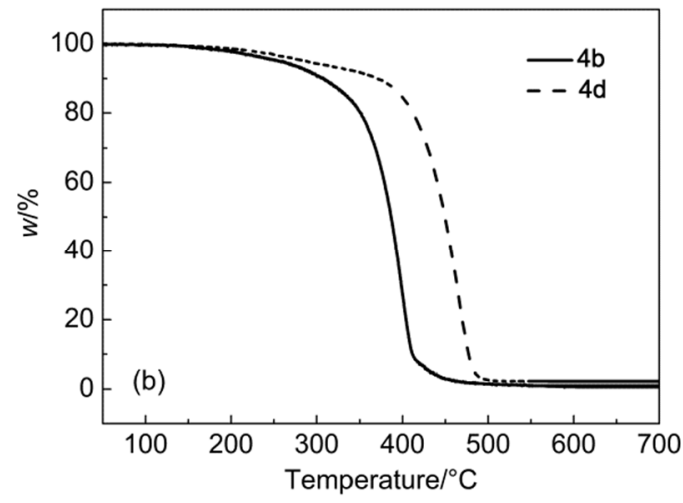




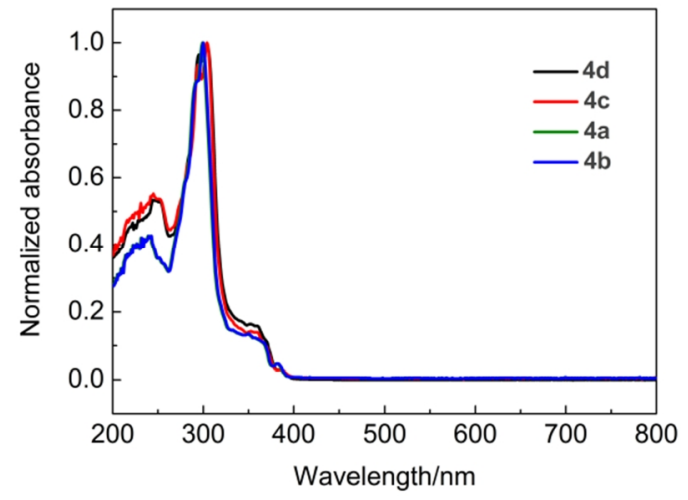

Fig.4 UV-Vis absorption spectra of $4 a, 4 b, 4 c$, and 4d in $\mathrm{CHCl}_{3}$ solution

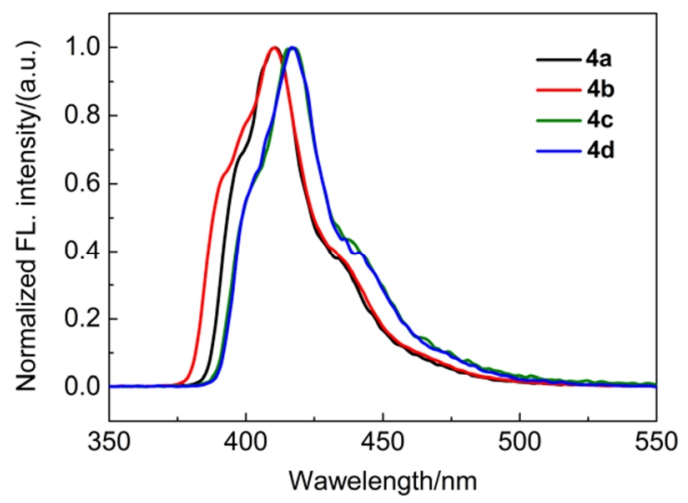

Fig.5 PL spectra of $4 a, 4 b, 4 c$, and $4 d$ in $\mathrm{CHCl}_{3}$ solution

Table 1 Physical parameters of $4 a, 4 b, 4 c$, and $4 d$

\begin{tabular}{ccccc}
\hline Compound & $\lambda_{\text {abs }} / \mathrm{nm}^{\mathrm{a}}$ & $\lambda_{\text {abs-onse }} / \mathrm{nm}^{\mathrm{a}}$ & $\Delta E^{\text {opt }} / \mathrm{eV}^{\mathrm{b}}$ & $\lambda_{\text {em }} / \mathrm{nm}$ \\
\hline 4a & 239,299 & 391 & 3.17 & 411 \\
$\mathbf{4 b}$ & 240,300 & 392 & 3.16 & 410 \\
$\mathbf{4 c}$ & 245,303 & 396 & 3.13 & 418 \\
4d & 244,304 & 395 & 3.14 & 416 \\
\hline
\end{tabular}

${ }^{\mathrm{a}}$ in $\mathrm{CHCl}_{3}$, with [substrate] $=2.0 \times 10^{-5} \mathrm{~mol} \cdot \mathrm{L}^{-1} \cdot{ }^{\mathrm{b}} \Delta E^{\text {opt }}=1240 / \lambda_{\text {abs-onset }}$

with $\mathbf{4 c}$ and $4 d, 4 a$ and $\mathbf{4 b}$ exhibited slightly blue-shifted PL spectra. This suggested that introducing phenyl substitutes at the 1-position of the silole core increased the degree of $\pi$-conjugation.

\subsection{Electrochemical properties}

The electrochemical properties of $\mathbf{4 a}, \mathbf{4 b}, \mathbf{4 c}$, and $\mathbf{4 d}$ were studied by cyclic voltammetry (CV). The silole compounds were dissolved in dichloromethane containing $0.1 \mathrm{~mol} \cdot \mathrm{L}^{-1}$ tetrabutylammonium perchlorate. The highest occupied molecular orbital (HOMO) energy level of the silole was calculated from the onset voltage of the oxidation peak with reference to ferrocene $(4.8 \mathrm{eV})$, using the following equation:

$\operatorname{HOMO}(\mathrm{eV})=-\left(E_{\text {onset }}^{\mathrm{ox}}-E_{\text {ferroene }}^{1 / 2}+4.8\right)$

The LUMO energy level was calculated from the HOMO energy level and the value of the optical band gap $\left(E^{\text {opt }}\right)$, according to the equation:

$\mathrm{LUMO}(\mathrm{eV})=\mathrm{HOMO}+E^{\mathrm{opt}}$.

The value of $E^{\text {opt }}$ was obtained from the UV-Vis absorption

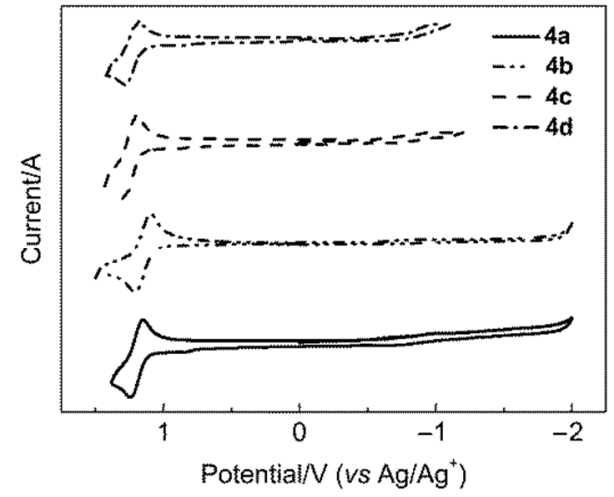

Fig.6 CV curves of $4 a, 4 b, 4 c$, and $4 d$

Table 2 Electrochemical data for $4 a, 4 b, 4 c$, and $4 d$

\begin{tabular}{ccccc}
\hline Compound & $E_{\text {onsed }}^{\text {ox }} / \mathrm{V}$ & $E^{\text {opt }} / \mathrm{eV}$ & $E_{\mathrm{HOMO}} / \mathrm{eV}$ & $E_{\mathrm{LUMO}} / \mathrm{eV}$ \\
\hline $\mathbf{4 a}$ & 1.1959 & 3.17 & -5.50 & -2.33 \\
$\mathbf{4 b}$ & 1.1550 & 3.16 & -5.49 & -2.33 \\
$\mathbf{4 c}$ & 1.2633 & 3.13 & -5.56 & -2.43 \\
$\mathbf{4 d}$ & 1.2412 & 3.14 & -5.54 & -2.40 \\
\hline
\end{tabular}

spectrum. Fig.6 shows CV curves of the compounds. Their corresponding electrochemical properties are given in Table 2.

All four siloles exhibited a single reversible oxidation couple, with an $E^{\text {ox }}$ onset in the range of 1.15-1.27 V. This corresponded to a HOMO energy level of -5.49 to $-5.56 \mathrm{eV}$. Their deep HOMO levels implied that they possessed good chemical stability under ambient conditions, and that they were resistant toward oxidative doping in the presence of air.

No reduction peaks were detected in the studied potential range. Therefore, the LUMO energy level of the silole was determined from the onset of the UV-Vis absorption spectrum. The estimated LUMO energy levels of $\mathbf{4 a}, \mathbf{4 b}, \mathbf{4 c}$, and $4 \mathbf{d}$ were $-2.33,-2.33,-2.43$, and $-2.40 \mathrm{eV}$, respectively.

\subsection{Theoretical calculations}

To better understand the photophysical properties of the siloles, theoretical calculations were performed using density function theory (DFT) calculations with a $\mathrm{B} 3 \mathrm{LYP} / 6-31 \mathrm{G}(d, p)$ basis set, using the Gaussian 09 software package ${ }^{33,34}$. Electronic excitation from the HOMO to LUMO produced the excited state. Thus, understanding the orbital features can enhance our understanding of the nature of the optically accessible excited state. The simulated electron distributions of the HOMO and the LUMO of $\mathbf{4 a}, \mathbf{4 b}, \mathbf{4 c}$, and $\mathbf{4 d}$ are shown in Fig.7. The electron clouds of the HOMO and LUMO of the four compounds were mainly located on the central conjugated backbones consisting of silole and naphthalene rings. The HOMO and LUMO showed no obvious contributions from the $\pi$-orbitals of 1,1-diaryl groups. Thus, varying the substituent on the silicon atom appeared to affect the electronic structure through a principally inductive mechanism. This has been proposed in previous reports ${ }^{32}$. However, it has also been suggested that $\pi$-effects are significant when the 


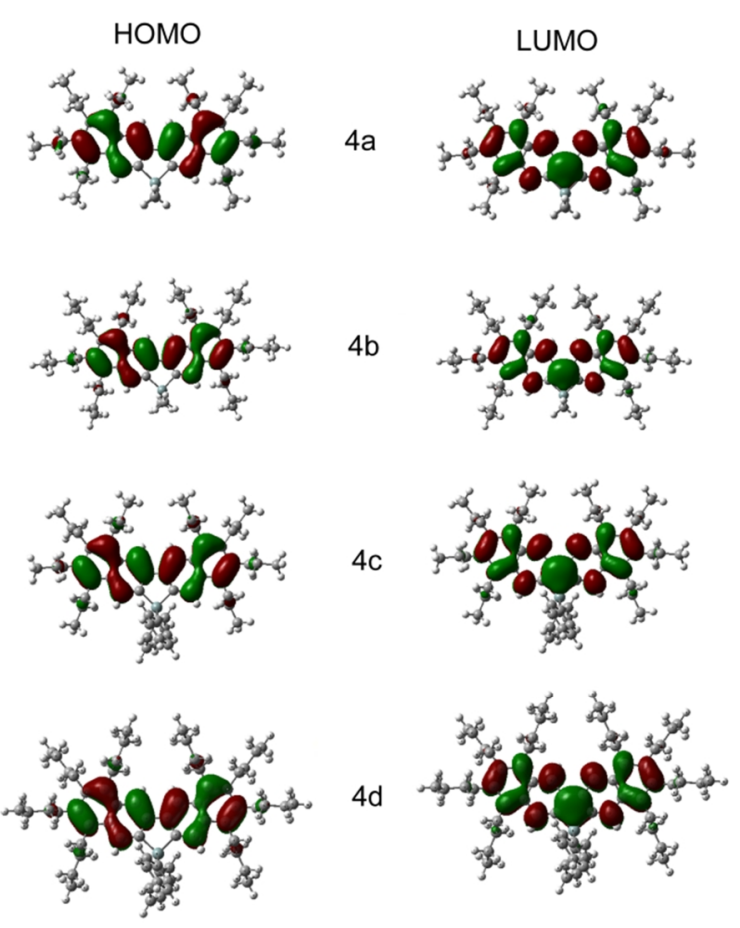

Fig.7 Optimized molecular structures and molecular orbital amplitude plots of the HOMO and LUMO electron distributions for $4 a, 4 b, 4 c$, and $4 d$

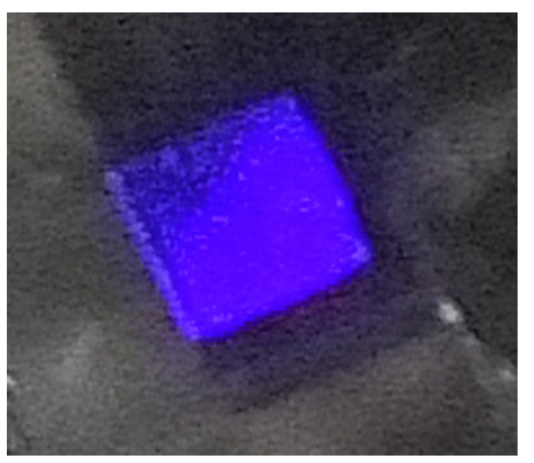

Fig.8 Electroluminescence of an OLED device containing $4 \mathrm{~b}$

1,1-substituents are phenyl groups ${ }^{32}$.

\subsection{Electroluminescence}

The EL properties of $\mathbf{4 b}$ were evaluated by incorporating it into a multilayered undoped organic light-emitting diode (OLED). The device configuration was ITO/NPB (30 $\mathrm{nm}) /$ silole $(30 \mathrm{~nm}) /$ Bphen $(30 \mathrm{~nm}) / \mathrm{LiF}(0.8 \mathrm{~nm}) / \mathrm{Al}(120 \mathrm{~nm})$. A typical device was fabricated with NPB as the hole transport layer (HTL, $30 \mathrm{~nm}$ ), 4b as the emitting layer (EML, $30 \mathrm{~nm}$ ), Bphen served as electron-transporting layer (ETL, $30 \mathrm{~nm}$ ). The device structure is shown in Fig.1. The device had a low turn-on voltage of $4.0 \mathrm{~V}$, and produced bright blue emission as shown in Fig.8. This demonstrated that $\mathbf{4 b}$ could function as an emitting material in an EL device. Further optimization could potentially improve the device performance. Further investigation and optimization of EL devices based on $\mathbf{4 a}, \mathbf{4 b}$, $\mathbf{4 c}$, and $\mathbf{4 d}$ is ongoing.

\section{Conclusions}

A series of dinaphthalene-fused siloles were synthesized via a straightforward approach involving coupling and lithiation reactions. The siloles were soluble in common organic solvents including chloroform, tetrahydrofuran, ethyl acetate, and dimethylformamide. The siloles were characterized by ${ }^{1} \mathrm{H}$ and ${ }^{13} \mathrm{C}$ NMR spectroscopy and HRMS. TGA and DSC measurements showed that their decomposition temperatures at $5 \%$ weight loss occurred at approximately $300{ }^{\circ} \mathrm{C}$, which indicated good thermal stability. UV-Vis absorption spectroscopy, photoluminescence spectroscopy, cyclic voltammetry and density functional theory calculations showed that the four compounds had similar electronic and optical properties. Their deep HOMO energy levels of approximately $5.50 \mathrm{eV}$ resulted in their good chemical stability at ambient conditions. The phenyl ring at the 1-position of the silole ring affected their photophysical properties, including slightly red-shifting the absorption and emission spectra. A multilayer electroluminesc ent device containing $\mathbf{4 b}$ as a light-emitting layer produced bright blue emission. This indicated that such silole compounds have potential in electroluminescent applications. Device optimization and the syntheses of siloles with other substituents are now in progress, to further the application of such siloles.

\section{References}

(1) Chen, H. Y.; Hou, J.; Hayden, A. E.; Yang, H.; Houk, K. N.; Yang, Y. Adv. Mater. 2010, 22 (3), 371. doi: 10.1002/adma.200902469

(2) Chen, B.; Jiang, Y.; Chen, L.; Nie, H.; He, B.; Lu, P.; Sung, H. H. Y.; Williams, I. D.; Kwork, H. S.; Qin, A.; Zhao, Z.; Tang, B. Z. Chem. -Eur. J. 2014, 20 (7), 1931. doi: 10.1002/chem.201303259

(3) Shimizu, M.; Mochida, K.; Hiyama, T. J. Phys. Chem. C 2011, 115 (22), 11265. doi: 10.1021/jp201168x

(4) Shimizu, M.; Mochida, K.; Katoh, M.; Hiyama, T. J. Phys. Chem. C 2010, 114 (21), 10004. doi: 10.1021/jp103410x

(5) Toal, S. J.; Jones, K. A.; Magde, D.; Trogler, W. C. J. Am. Chem. Soc. 2005, 127 (33), 11661. doi: 10.1021/ja052582w

(6) Lu, G.; Usta, H.; Risko, C.; Wang, L.; Facchetti, A.; Ratner, M. A.; Marks, T. J. J. Am. Chem. Soc. 2008, 130 (24), 7670. doi: $10.1021 / \mathrm{ja} 800424 \mathrm{~m}$

(7) Hou, J.; Chen, H. Y.; Zhang, S.; Li, G.; Yang, Y. J. Am. Chem. Soc. 2008, 130 (48), 16144. doi: 10.1021/ja806687u

(8) Chu, T. Y.; Lu, J.; Beaupre, S.; Zhang, Y.; Pouliot, J. R.; Wakim, S.; Zhou, J.; Leclerc, M.; Li, Z.; Ding, J.; Tao, Y. J. Am. Chem. Soc. 2011, 133 (12), 4250. doi: 10.1021/ja200314m

(9) Chen, H. Y.; Lam, W. Y.; Luo, J. D.; Ho, Y. L.; Tang, B. Z.; Zhu, D. B.; Wong, M.; Kwok, H. S. Appl. Phys. Lett. 2002, 81 (4), 574. doi: $10.1063 / 1.1495542$

(10) Tamao, K.; Uchida, M.; Izumizawa, T.; Furukawa, K.; Yamaguchi, $\mathrm{S}$.

J. Am. Chem. Soc. 1996, 118 (47), 11974. doi: 10.1021/ja962829c

(11) Liu, M. S.; Luo, J.; Jen, A. K. Y. Chem. Mater. 2003, 15 (18), 3496. doi: $10.1021 / \mathrm{cm} 030063 \mathrm{r}$ 
(12) Chen, H.; Yang, T.; Li, J. W.; Zhang, X. W.; Qian, Y.; Xie, L. H.; Huang, W. Acta Phys. -Chim. Sin. 2016, 26 (9), 2346. [陈 昊, 杨 涛, 李杰伟, 张新稳, 钱 妍, 解令海, 黄 维. 物理化学学报, 2016, 26 (9), 2346.] doi: 10.3866/PKU.WHXB201605163

(13) Wang, F.; Luo, J.; Yang, K. X.; Chen, J. W.; Huang, F.; Cao, Y. Macromolecules 2005, 38 (6), 2253. doi: 10.1021/ma047561I

(14) Ren, Y.; Lam, J. W. Y.; Dong, Y. Q.; Tang, B. Z.; Wong, K. S. J. Phys. Chem. B 2005, 109 (3), 1135. doi: 10.1021/jp046659z

(15) Qi, Q. J.; Wu, X. M.; Hua, Y. L.; Hou, Q. C.; Dong, M. S.; Mao, Z. Y.; Yin, B.; Yin, S. G. Org. Electron. 2010, 11 (3), 503. doi: 10.1016/j.orgel.2009.11.032

(16) Wang, M.; Zhang, D. Q.; Zhang, G. X.; Tang, Y. L.; Wang, S.; Zhu, D. B. Anal. Chem. 2008, 80 (16), 6443. doi: 10.1021/ac801020v

(17) Taydakov, I. V.; Akkuzina, A. A.; Avetisov, R. I.; Khomyako, A. V.; Saifutyarov, R. R.; Avetissov, I. C. J. Lumin. 2016, 177, 31. doi: 10.1016/j.jlumin.2016.04.017

(18) Du, X. B.; Wang, Z. Y. Chem. Commun. 2011, 47, 4276. doi: 10.1039/C1CC00066G

(19) Yin, S. C.; Zhang, J.; Feng, H. K.; Zhao, Z. J.; Xu, L. W.; Qiu, H. Y.; Tang B. Z. Dyes Pigm. 2012, 95 (2), 174. doi: 10.1016/j.dyepig.2012.04.007

(20) Zhang, Q. W.; An, K.; He, W. Angew. Chem. 2014, 126 (22), 5773. doi: 10.1002/ange.201400828

(21) Murai, M.; Matsumoto, K.; Takeuchi, Y.; Takai, K. Org. Lett. 2015, 17 (12), 3102. doi: 10.1021/acs.orglett.5b01373

(22) Ohshita, J.; Lee, K. H.; Kimura, K.; Kunai, A. Organometallics, 2004, 23 (23), 5622. doi: 10.1021/om049656h

(23) Ohshita, J.; Kai, H.; Sumida, T.; Kunai, A.; Adachi, A.; Sakamaki, K.; Okita, K. J. Organomet. Chem. 2002, 642 (1-2), 137. doi: 10.1016/S0022-328X(01)01257-8

(24) Kunai, A.; Ohshita, J.; Iida, T.; Kanehara, K.; Adachi, A.; Okita, K.
Synth. Met. 2003, 137 (1-3), 1007.

doi: 10.1016/S0379-6779(02)00854-8

(25) Song, X. N.; Wang, G. W.; Chang, Y.; Ma, Y.; Wang, C. K. Acta Phys. -Chim. Sin. 2016, 32 (4), 943. [宋秀能, 王广伟, 常 燕, 马 勇, 王传奎. 物理化学学报, 2016, 32 (4), 943.] doi: 10.3866/PKU.WHXB201601291

(26) Liang, Y.; Geng, W. Z.; Wei, J. N.; Xi, Z. F. Angew. Chem.-Ger. Edit. 2012, 124 (8), 1970. doi: 10.1002/ange.201108154

(27) Volz, H.; Kowarsch, H. J. Organomet. Chem. 1977, 136 (2), c27. doi: 10.1016/S0022-328X(00)82128-2

(28) Zhao, J. C.; Qiu, D. F.; Shi, J. W.; Wang, H. J. Org. Chem. 2012, 77 (6), 2929. doi: 10.1021/jo202111z

(29) Yasuike, S.; Hagiwara, J.; Danjo, H.; Kawahata, M.; Kakusawa, N.; Yamaguchi, K.; Kurita, J. Heterocycles, 2009, 78 (12), 3001. doi: 10.3987/COM-09-11812

(30) Bayrak, R.; Akçay, H. T.; Durmuş, M.; Değirmencioğlu, İ. J. Organomet. Chem. 2011, 696 (23), 3807. doi: 10.1016/j.jorganchem.2011.09.002

(31) Zhao, Z. J.; Liu, D. D.; Mahtab, F.; Xin, L. Y.; Shen, Z. F.; Yu, Y.; Chan, C. Y. K.; Lu, P.; Lam, J. W. Y.; Sung, H. H. Y.; Williams, I. D.; Yang, B.; Ma, Y. G.; Tang, B. Z. Chem.-Eur. J. 2011, 17 (21), 5998. doi: 10.1002/chem.201003382

(32) Yamaguchi, S.; Jin, R. Z.; Tamao, K. J. Organomet. Chem. 1998, 559 (1-2), 73. doi: 10.1016/S0022-328X(98)00425-2

(33) Siddiqui, S. A.; Al-Hajry, A.; Al-Assiri, M. S. Int. J. Quantum Chem. 2016, 116 (5), 339. doi: 10.1002/qua.25034

(34) Foresman, J. B.; Head-Gordon, M.; Pople, J. A.; Frisch, M. J. J. Phys. Chem. 1992, 96 (1), 135. doi: 10.1021/j100180a03 